\title{
PENGARUH PEMBERIAN JUS MELON TERHADAP KADAR HEMOGLOBIN PADA IBU HAMIL YANG MENGKONSUMSI TABLET FE
}

(Di Puskesmas Plupuh II Wilayah Kerja Dinas Kesehatan Kabupaten Sragen)

Effect Of Consumption Of Melon Juice On Hemoglobin Levels Of Pregnant Fe In Plupuh II Health Care Sragen District

\author{
Eni Rumiyati ${ }^{1}$, Anies ${ }^{2}$, Apoina Kartini ${ }^{3}$ \\ Universitas Diponegoro \\ (enirumiyatie@gmail.com)
}

\begin{abstract}
ABSTRAK
Latar Belakang : Pencegahan anemia selama kehamilan dilakukan dengan pemberian tablet Fe selama 90 hari. Konsumsi vitamin C yang cukup diperlukan untuk membantu penyerapan Fe. Melon (CucumisMelo L) merupakan salah satu bahan makanan yang mengandung vitamin $\mathrm{C}$ dan vitamin $\mathrm{A}$ yang dapat membantu proses penyerapan zat besi. Penelitian ini membuktikan pengaruh pemberian jus melon terhadap perubahan kadar hemoglobin ibu hamil yang mengkonsumsi tablet Fe.

Metode : Penelitian ini menggunakan metodequasy experiment dengan rancangan non randomized pretest and posttest with control group design, Pengukuran hemoglobin menggunakan alat mutiple quick check. Penelitian dilakukan pada 60 responden yang terbagi menjadi 4 kelompok (kontrol, pemberian jus melon 200 gr, pemberian jus melon 150 gr dan pemberian ju melon 100 gr). Analisis data dengan t-test dependent dan Anova.

Hasil : Ada perubahan kadar hemoglobin pada kelompok perlakuan pemberian jus melon 100 gr dengan nilai p-value 0,004 dan pemberian jus melon 200 gr dengan nilai p-value 0,000 , semetara untuk pemberian jus melon 150 gr tidak terdapat perubahan yang signifikan terhadap kadar hemoglobin pada ibu hamil. Terdapat perbedaan kadar hemoglobin pada perlakuan jus melon 200 gr dengan kontrol dengan $p=0,001$ dan terdapat perbedaan kadar hemoglobin perlakuan jus melon 200 gr dengan jus 100 gr dengan $p=0,017$ dengan IK 95\%.

Simpulan: Ada pengaruh pemberian jus melon terhadap kadar hemoglobin pada ibu hamil yang mengkonsumsi tablet Fe.
\end{abstract}

Kata kunci: Jus Melon, Kadar Hemoglobin, Ibu Hamil

\section{ABSTRACT}

Background :Prevention of anemia during pregnancy is done by giving Fe tablets for 90 days at a dose of $60 \mathrm{mg}$. Each tablet contains FeSO4 $320 \mathrm{mg}$ (iron $60 \mathrm{mg}$ ). In addition to consuming iron tablets, pregnant women need to be supported by nutritional patterns that can help absorb hemoglobin in the form of vitamin $C$. Melon (CucumisMelo L) is one of the ingredients that contain several compounds 
needed in the synthesis of hemoglobin namely vitamin $C$ and vitamin $A$ which can help process iron absorption. .

Objective :Proving the effect of giving melon juice to changes in hemoglobin levels of pregnant women who consume Fe tablets.

Research Method :This study a quasy experiment method with a non-randomized design pretest and posttest with control group design, hemoglobin measurements using multiple instruments quick check. The study was conducted on 60 respondents with4 treatment groups (Fe tablets and melon juice $200 \mathrm{gr}, 150 \mathrm{gr}$ and $100 \mathrm{gr}$ ). Using t-test dependent and Anova.

Results :There was a change in hemoglobin level in the treatment group giving $100 \mathrm{~g}$ of melon juice with a p-value of 0.004 and $200 \mathrm{~g}$ of melon juice with a $p$ value of 0.000, while for melon juice $150 \mathrm{gr}$ there was no significant change in hemoglobin levels in pregnant women. There was a difference in hemoglobin levels in the treatment of $200 \mathrm{gr}$ melon juice with control with $p=0.001$ and there were differences in hemoglobin levels in the treatment of $200 \mathrm{gr}$ melon juice with 100 gr juice with $p=0.017$ with $95 \%$ IK.

Conclusion: Giving melon juice and Fe tablets significantly affected changes in Hemoglobin levels in pregnant women.

Keywords : : Melon, Hemoglobin Levels, Pregnant Women

\section{PENDAHULUAN}

Angka Kematian Ibu (AKI) merupakan salah satu indikator penting dalam menilai derajad keberhasilan pembangunan kesehatan suatu negara. Penyebab AKI terbesar di Indonesia adalah perdarahan, infeksi dan eklampsi. Selain itu ada faktor pendukung yaitu 4 Terlalu. 4 Terlalu tersebut adalah terlalu muda, terlalu tua, terlalu banyak anak dan terlalu sering hamil (Saifuddin, 2002). Anemia pada ibu hamil menjadi penyebab utama terjadinya pendarahan yang merupakan faktor kematian utama ibu di Indonesia (Depkes RI, 2008).

AKI di Indonesia pada tahun 2015 berada pada 305 per 100.000 kelahiran hidup (Kemenkes, 2017). Target SGDsadalahdapat menurunkan AKI menjadi 70 per 100.000 kelahiranhidup. AKI di Jawa Tengah pada tahun 2016 adalah 109,65 per 100.000 kelahiran hidup, sedangkan AKI yang tercatat di Kabupaten Sragen sebesar 17 kasus (Dinkes Jateng, 2016).

Dampak kekurangan zat besi pada wanita hamil dapat menimbulkan gangguan atau hambatan pada pertumbuhan janin baik sel tubuh maupun sel otak. Anemia gizi dapat mengakibatkan kematian janin dalam kandungan, abortus, cacat bawaan, BBLR, anemia pada bayi yang dilahirkan sehingga hal ini menyebabkan morbiditas dan mortalitas ibu dan kematian perinatal secara bermakna lebih tinggi. Anak yang dikandung oleh ibu yang menderita anemia juga akan mengalami penurunan kecerdasan intelejensi. (Sarwono, 2010).

Frekuensi ibu hamil anemia di Indonesia relatif tinggi yaitu 63,5\%. Kekurangan gizi dan perhatian yang kurang ibu hamil merupakan predisposis anemia difisiensi besi di Indonesia (Saifuddin, 2006). Menurut WHO kejadian anemia kehamilan berkisar antara 20\% sampai 89\% dengan menetapkan $\mathrm{Hb} 11$ 
gr\% sebagai dasarnya. Pada pengamatan menunjukkan bahwa kebanyakan anemia yang diderita di masyarakat adalah karena kekurangan zat besi yang dapat diatasi melalui pemberian zat besi secara teratur dan dengan adanya pemberian peningkatan gizi pada ibu hamil (Manuaba, 2008).

Anemiadi Indonesia telah ditanggulangi pemerintah dengan mencanangkan pemerataan pendistribusian tablet $\mathrm{Fe}$ ke pelayanan kesehatan untuk dapat dibagikan keseluruh ibu hamil secara gratis. Anemia selama kehamilan dapat dicegah dengan pemberian tablet Fe selama 90 hari dengan dosis $60 \mathrm{mg}$. Tiap tablet mengandung FeSO4 320mg (zat besi 60mg) dan asam folat 500 $\mu \mathrm{g}$. Tablet besi sebaiknya tidak diminum dengan teh atau kopi, karena akan menghambat penyerapannya (Depkes RI, 2008). Tablet besi dapat cepat terabsorbsi dengan minuman atau buah yang mengandung vitamin $\mathrm{C}$ dan banyak terdapat pada tamanam buah-buahan (Shinta, 2012).

Penyerapan zat besi sangat dipengaruhi oleh ketersediaan vitamin $\mathrm{C}$ dalam tubuh ibu. Vitamin $\mathrm{C}$ berperan dalam proses penyerapan zat besi yaitu membantu mereduksi besi ferri $\left(\mathrm{Fe}^{3+}\right)$ menjadi ferro $\left(\mathrm{Fe}^{2+}\right)$ dalam usus halus sehingga mudah diabsorbsi, proses reduksi tersebut akan semakin besar bila $\mathrm{pH}$ didalam lambung semakin asam. Vitamin $\mathrm{C}$ dapat menambah keasaman sehingga dapat meningkatkan penyerapan zat besi hingga $30 \%$.

Kebutuhan vitamin $\mathrm{C}$ seorang ibu hamil meningkat dimana ibu hamil membutuhkan $85 \mathrm{mg}$ perhari vitamin C. Kandungan Vitamin $\mathrm{C}$ banyak terdapat pada buah-buahan. Buah sangat baik untuk ibu hamil dan janin yang ada dalam kandungan. Buah memiliki rasa yang menyegarkan dan bisa mengurangi efek mual pada ibu hamil salah satunya adalah jenis buah seperti melon. Melon dapat diolah menjadi jus atau langsung di makan (Alfi, 2013).

Buah melon 94\% mengandung air sehingga memberikan rasa dingin dan menyejukkan. Melon baik untuk pencernaan karena kandungan seratnya yang cukup tinggi serta kandungan vitamin $\mathrm{C}$ yang cukup tinggi yang berperan sebagai antioksidan (Rukmana,1994).Melon mengandung begitu banyak nutrisi penting yang dibutuhkan oleh tubuh. Dalam 100 gram daging buah melon terdapat zat gizi penting seperti karbohidrat 14,8 gr, protein 1,55 gr, lemak 0,5 gr, potassium 546,9 $\mathrm{mg}$, vitamin A 5.706,5 IU dan vitamin C 74,7 mg (Harjana, 2013).

Melon dengan kandungan vitamin $\mathrm{C}$ dan vitamin A didalamnya diharapkan akan membantu penyerapan zat besi yang dikonsumsi oleh ibu hamil, sehingga prevalensi anemia pada ibu hamil dapat menurun. Dari uraian latar belakang tersebut membuat peneliti tertarik untuk melakukan penelitian tentang pengaruh jus melon terhadap perubahan kadar hemoglobin pada ibu hamil.

\section{METODE PENELITIAN}

Jenis penelitianini bersifat eksperimental. Penelitian ini menggunakan metode penelitian eksperimen semu atau quasy experiment dengan rancangan non randomized pretest and posttest with control group design yang digunakan untuk mengetahui pengaruh konsumsi melon dengan suplementasi tablet Fe terhadap peningkatan kadar hemoglobin pada kehamilan. 
Penelitian dilakukan pada 60 responden ibu hamil trimester II-III yang terbagi menjadi 4 kelompok (kontrol, pemberian jus melon 200 gr, pemberian jus melon 150 gr dan pemberian ju melon 100 gr). Alat pemeriksaan kadar hemoglobin yang digunakan adalah Hemoglobin Testing System Quick-Check set untuk mengukur kadar hemoglobin sampel sebelum dan sesudah perlakuan.Pemberian jus melon dilakukan selama 7 hari. Pemeriksaan hemoglobin dilakukan pada hari pertama dan hari ke delapan. Analisis data dengan t-test dependent dan Anova.

\section{HASIL DAN PEMBAHASAN}

Tabel 1 Persentase karakteristik responden berdasarkan Umur, Pendidikan dan Gravida pada Kelompok Kontrol dan Kelompok Perlakuan

\begin{tabular}{|c|c|c|c|c|}
\hline \multirow[t]{2}{*}{ Keterangan } & \multicolumn{4}{|c|}{ Kelompok } \\
\hline & $\begin{array}{c}\text { Kelompok } \\
\text { Kontrol }\end{array}$ & $\begin{array}{c}\text { Kelompok } \\
\text { Melon } 100 \mathrm{gr}\end{array}$ & $\begin{array}{c}\text { Kelompok } \\
\text { Melon } 150 \mathrm{gr}\end{array}$ & $\begin{array}{c}\text { Kelompok } \\
\text { Melon } 200 \text { gr }\end{array}$ \\
\hline \multicolumn{5}{|l|}{ Umur Ibu (Tahun) } \\
\hline - $\quad$ Min - Max & $20-35$ & $19-36$ & $18-31$ & $18-35$ \\
\hline \multicolumn{5}{|l|}{ Pendidikan } \\
\hline$-\quad \mathrm{SD}$ & $1(6,7)$ & $4(26,7)$ & $1(6,7)$ & $3(20)$ \\
\hline - $\quad$ SMP & $6(40)$ & $4(26,7)$ & $7(46,6)$ & $5(33,3)$ \\
\hline - $\quad$ SMA & $8(53,3)$ & $6(40)$ & $6(40)$ & $6(40)$ \\
\hline$-\quad \mathrm{PT}$ & $0(0)$ & $1(6,6)$ & $1(6,7)$ & $1(6,7)$ \\
\hline \multicolumn{5}{|l|}{ Gravida } \\
\hline$-\quad 1$ & $4 \quad(26.7)$ & $7(46,7)$ & $7(46,7)$ & $7(46,7)$ \\
\hline 2 & $11(73.3)$ & $5(33,3)$ & $7(46,7)$ & $6(40)$ \\
\hline 3 & & $2(13,3)$ & $1(6,6)$ & $2(13,3)$ \\
\hline 4 & & $1(6,7)$ & & \\
\hline
\end{tabular}

Berdasarkan tabel 1 mayoritas karakteristik responden berdasarkan umur masih tergolong ke dalam usia reproduktif yang sehat, dimana dapat dilihat ratarataumur pada kelompok kontrol adalah 26 tahun dan rata-rata umur kelompok perlakuan adalah umur 25 tahun.Mayoritastingkat pendidikan kelompok kontrol adalah SMA sebanyak 8 orang $(53,3 \%)$, mayoritas tingkat pendidikan kelompok perlakuan melon 100 gram adalah SMA sebanyak 6 orang (40,0\%), mayoritas tingkat pendidikan kelompok perlakuan melon 150 gram adalah SMA sebanyak 6 orang $(40,0 \%)$ dan mayoritas umur kelompok perlakuan melon 200 gram adalah SMA juga sebanyak 6 orang $(40,0 \%)$. Reratakehamilan pada kelompok kontrol hingga kelompok perlakuan melon 100 gram, melon 150 gram dan melon 200 gram adalah pada periode kehamilan anak ke 2 atau multigravida.

Tabel 2 Status anemia sebelum dan sesudah perlakuan

\begin{tabular}{lccccccc}
\hline Kelompok & \multicolumn{2}{c}{$\begin{array}{c}\text { Tidak Anemia } \\
(\mathrm{Hb}: 11 \mathrm{gr} \%)\end{array}$} & \multicolumn{2}{c}{$\begin{array}{c}\text { Anemia Ringan } \\
(\mathrm{Hb}: 9-10 \mathrm{gr} \%)\end{array}$} & $\begin{array}{c}\text { Anemia Sedang } \\
(\mathrm{Hb}: 7-8 \mathrm{gr} \%)\end{array}$ & Total \\
\cline { 2 - 7 } & Pre & Post & Pre & Post & Pre & Post & \\
\hline Kontrol & 0 & 1 & 10 & 9 & 5 & 5 & 15 \\
& $(0)$ & $(6,7)$ & $(66,7)$ & $(60)$ & $(33,3)$ & $(33,3)$ & $(100)$ \\
Jus melon & 4 & 1 & 3 & 7 & 8 & 7 & 15 \\
100 gr & $(26,7)$ & $(6,7)$ & $(20)$ & $(46,7)$ & $(53,3)$ & $(46,7)$ & $(100)$ \\
Jus melon & 0 & 2 & 8 & 8 & 7 & 5 & 15 \\
150 gr & $(0)$ & $(13,3)$ & $(53,3)$ & $(53,3)$ & $(46,7)$ & $(33,3)$ & $(100)$ \\
Jus melon & 0 & 2 & 4 & 11 & 11 & 2 & 15 \\
200 gr & $(0)$ & $(13,3)$ & $(26,7)$ & $(73,3)$ & $(73,3)$ & $(13,3)$ & $(100)$ \\
\hline
\end{tabular}


Berdasarkan tabel 2 menunjukkan bahwa responden pada kelompok kontrol maupun kelompok perlakuan masuk dalam kriteria anemia karena memiliki kadar hemoglobin kurang dari $11 \mathrm{~g} \%$. Responden terbanyak pada kelompok kontrol sebelum dan sesudah penelitian masuk status anemia ringan. Responden terbanyak pada kelompok perlakuan jus melon 100 gr sebelum perlakuan masuk kriteria anemia sedang dan sesudah perlakuan masuk status anemia ringan dan sedang. Responden terbanyak pada kelompok perlakuan jus melon 150 gr sebelum dan sesudah perlakuan masuk kriteria anemia ringan. Responden pada kelompok perlakuan jus melon 200 gr sebelum perlakuan masuk kriteria anemia sedang dan sesudah perlakuan masuk kriteria anemia ringan.

Tablet 3 Hasil Uji Normalitas Data

\begin{tabular}{llccc}
\hline \multicolumn{1}{c}{ Kelompok } & Kadar $\mathrm{Hb}$ & Mean & Sig. & Ket. \\
\hline Kontrol & Pretest & 9,233 & 0,925 & Normal \\
& Postest & 9,487 & 0,555 & Normal \\
Perlakuan jus melon & Pretest & 6,380 & 0,025 & Tidak Normal \\
100 gr & Postest & 9,000 & 0,057 & Tidak Normal \\
Perlakuan jus melon & Pretest & 8,707 & 0,958 & Normal \\
150 gr & Postest & 10,520 & 0,209 & Normal \\
Perlakuan jus melon & Pretest & 8,387 & 0,623 & Normal \\
200 gr & Postest & 10,647 & 0,108 & Normal \\
\hline
\end{tabular}

Berdasarkan tabel 3 hasil uji normalitas dengan Shapiro-Wilkjika data terdistribusi normal, jika data tidak terdistribui normal dengan Wilcoxcon. Uji normalitas data pada kelompok kontrol, perlakuan jus 150 dan 200 berdistribusi normal dengan nilai sign $>0,05$. Uji normalitas data pada kelompok perlakuan jus 100 berdistribusi tidak normal dengan nilai sign $<0,05$.

Tabel 4 Hasil Uji Paired Sampel t-Test

\begin{tabular}{lllcc}
\hline \multicolumn{1}{c}{ Kelompok } & Kadar Hb & Mean & $t$ & p-value \\
\hline Kontrol & Pretest- & 9,233 & 2,572 & 0,022 \\
& Postest & 9,487 & & \\
Perlakuan jus melon 100 gr & Pretest- & 6,380 & 4,990 & 0,004 \\
& Postest & 9,000 & & \\
\multirow{2}{*}{ Perlakuan jus melon 150 gr } & Pretest- & 8,707 & \multirow{2}{*}{1,616} & 0,128 \\
& Postest & 10,520 & & \\
Perlakuan jus melon 200 gr & Pretest- & 8,387 & 6,525 & 0,000 \\
& Postest & 10,647 & & \\
\hline
\end{tabular}

Berdasarkan tabel 4 Terbukti ada perubahan kadar hemoglobin yang signifikan pada ibu hamil sebelum dan sesudah mengkonsumsi tablet Fe pada semua kelompok baik kontrol maupun kelompok perlakuan, terlihat dari hasil uji $\mathrm{t}_{\text {-test }}$ dependent atau paired sampel $t$-test diperoleh nilai $\mathrm{p}$-value $<0,05$. 
Jurnal Kebidanan Indonesia. Vol 10 No 2. Juli 2019 (41 - 49)

Tabel 5 Hasil Uji One Way Anova

\begin{tabular}{llcc}
\hline \multicolumn{1}{c}{ Perlakuan } & Mean & F & Sig. \\
\hline Perlakuan & 19,133 & 4,990 & 0,004 \\
Kontrol & 71,567 & & \\
\hline
\end{tabular}

Berdasarkan tabel 5 Kadar hemoglobin responden kelompok kontrol dengan responden kelompok perlakuan yang baru mengkonsumsi jus melon selama 7 hari berturut-turut, menunjukkan terdapat perbedaan yang signifikan, dimana nilai $F_{\text {hitung }}$ sebesar 4,990 dengan p-value sebesar 0,004 > 0,05 yang berati signifikan. Dengan demikian menunjukkan ada perbedaan kadar hemoglobin antara responden kelompok kontrol dengan responden kelompok perlakuan.

Tabel 6. Perbandingan Hasil Kadar Hemoglobin Antar Kelompok

\begin{tabular}{lcccc}
\hline \multicolumn{1}{c}{ Kelompok } & \multirow{2}{*}{$\begin{array}{c}\text { Perbedaan } \\
\text { Rata-rata }\end{array}$} & \multicolumn{2}{c}{ IK 95\% } & $p$ \\
\cline { 3 - 4 } & & Minimum & Maksimum & \\
\hline Jus melon 200 gr & 1,11 & 4081 & 1,8052 & 0,001 \\
vs Kontrol & & & & 0,017 \\
\hline $\begin{array}{l}\text { Jus melon 200 gr } \\
\text { vs 100 gr }\end{array}$ & 1,55 & 2162 & 2.8771 & \\
\hline
\end{tabular}

Berdasarkan tabel 6 Terdapat perbedaan kadar hemoglobin perlakuan jus melon 200 gr dengan kontrol karena $p=0,001$ dan IK 95\% sehingga terdapat perbedaan kadar hemoglobin kelompok jus melon 200 gr dengan kontrol. Terdapat perbedaan kadar hemoglobin perlakuan jus melon 200 gr dengan jus 100 gr karena $p=0,017$ dan IK 95\% sehingga terdapat perbedaan kadar hemoglobin kelompok jus melon 200 gr dengan perlakuan jus 100 gr.

Usia ideal seorang wanita hamil adalah pada rentang umur 20-35 tahun dimana umur tersebut termasuk reproduksi sehat, dimana pada rentang usia tersebut jarang terjadi komplikasi kehamilan dan secara biologis telah dipersiapkan dengan baik dan matang untuk bereproduksi. Sebaliknya usia kurang dari 20 tahun secara biologis beresiko anemia sebab pada usia tersebut organ reproduksinya belum berfungsi secara optimal dan secara psikologis juga belum optimal emosinya dan cenderung labil sehingga mengakibatkan kurangnya perhatian terhadap kebutuhan zat-zat gizi selama hamil. Selain itu usia diatas 35 tahun juga rentan terjadi anemia karena daya tahan tubuh mulai menurun sehingga penyakit sering muncul (Sumiarsih, 2018).

Ibu hamil yang berumur kurang dari 20 tahun dan lebih dari 35 tahun 74,1\% menderita anemia dan wanita yang usia 20-35 tahun yaitu 50,5\% menderita anemia. Wanita yang berumur kurang dari 20 tahun atau lebih dari 35 tahun mempunyai resiko yang tinggi untuk hamil, karena akan membahayakan kesehatan dan keselamatan ibu hamil maupun janin, beresiko mengalami perdarahan dan dapat menyebabkan ibu mengalami anemia (Astriana, 2017).

Tingkat pengetahuan seseorang diperoleh dari pengalaman sendiri maupun pengalaman dari orang lain, serta dari latar belakang pendidikannya karena tingkat pendidikan dapat menentukan mudah tidaknya seseorang menyerap dan 
memahami ilmu pengetahuan khususnya tentang gizi yang diperoleh selama ini (Purwandari, 2016).

Tingkat pendidikan seseorang akan mempengaruhi dalam pengambilan keputusan terhadap suatu tindakan, ibu yang memiliki pendidikan tinggi akan terbuka menerima informasi baru sehingga menambah tingkat pengetahuan dan perilaku positif terhadap pemenuhan gizi saat kehamilan. Hasil penelitian Mariza, 2015 bahwa ada hubungan pendidikan dengan anemia ibu hamil, dimana ibu hamil dengan pendidikan rendah prevalensinya lebih besar dari pada ibu yang berpendidikan tinggi. Karena semakin tinggi pendidikan kemampuan menerima informasi yang berkaitan dengan kesehatan terutama pada ibu hamil anemia, seperti pengetahuan anemia dan pemilihan makanan tinggi besi dan banyaknya asupan zat besi.

Ibu dengan paritas tinggi mempunyai resiko 1,454 kali lebih besar untuk mengalami anemia di banding dengan paritas rendah. Adanya kecenderungan bahwa semakin banyak jumlah kelahiran (paritas) maka semakin tinggi angka kejadian anemia. Makin sering seorang mengalami kehamilan dan melahirkan akan makin banyak kehilangan zat besi dan menjadi makin anemis. Wanita yang sering mengalami kehamilan dan melahirkan semakin anemi karena banyak kehilangan zat besi.

Hemoglobin merupakan protein dalam eritrosit yang berfungsi sebagai pengangkut oksigen dari paru-paru ke seluruh tubuh. Hemoglobin juga mengangkut karbondioksida kembali menuju paru-paru untuk dikeluarkan dari tubuh. Pada ibu hamil terjadi peningkatan $30 \%$ sampai $40 \%$ volume plasma dalam darah sehingga terjadi pengenceran darah (hemodilusi). Hemodilusi ini merupakan proses penyesuaian diri dalam kehamilan yang bermanfaat untuk meringankan beban kerja jantung yang disebabkan peningkatan cardiac output akibat hipervolemia (Wiknjosastro, 2015). Berdasarkan hasil uji statistik untuk melihat perbedaan kadar hemoglobin antara kelompok kontrol yang hanya mengkonsumsi suplemen tablet $\mathrm{Fe}$ dengan kelompok perlakuan yang mengkonsumsi suplemen Fe dan konsumsi jus melon, menunjukkan bahwa ada perbedaan yang signifikan pada pemberian jus melon baik $100 \mathrm{gr}, 150 \mathrm{gr}$ maupun 200 gr/dl dengan kadar hemoglobin pada ibu hamil. Rata-rata kadar hemoglobin responden yang mengkonsumsi tablet $\mathrm{Fe}$ dan jus melon lebih tinggi daripada responden yang hanya mengkonsumsi tablet Fe saja.

Penyerapan Fe akan lebih maksimal apabila dikonsumsi bersamaan dengan vitamin C. Vitamin $\mathrm{C}$ adalah salah satu zat gizi yang berperan dalam pembentukan hemoglobin yang berpengaruh terhadap absorbsi dan pelepasan besi dari transferin ke dalam jaringan tubuh. Peranan vitamin $\mathrm{C}$ dalam proses penyerapan zat besi yaitu membantu mereduksi besi ferri $\left(\mathrm{Fe}^{3+}\right)$ menjadi besi ferro $\left(\mathrm{Fe}^{2+}\right)$ dalam usus halus sehingga mudah diabsorbsi, proses reduksi tersebut akan semakin besar bila $\mathrm{pH}$ di dalam lambung semakin asam. Vitamin $\mathrm{C}$ dapat menambah keasaman sehingga dapat meningkatkan penyerapan zat besi hingga 30\% (Soeditama, 2006). Vitamin C menghambat pembentukan hemosederin yang sukar dimobilisasi untuk membebaskan besi bila diperlukan. Absorbsi besi dalam bentuk nonheme meningkat empat kali lipat bila ada vitamin $\mathrm{C}$. Vitamin $\mathrm{C}$ berperan dalam memindahkan besi dari transferin di dalam plasma ke ferritin hati. 
Sedangkan faktor penghambat absorbs zat besi dipengaruhi oleh zat yang sebagian besar terdapat dalam makanan yang berasal dari tumbuh-tumbuhan. Penghambat paling kuat adalah senyawa polifenol seperti tannin dalam teh. Teh dapat menurunkan absorbsi zat besi ke tubuh sampai $80 \%$ sebagai akibat terbentuknya komplek besi-tanat (Sumiyarsi, 2018).

Meningkatnya kadar hemoglobin bagi responden yang mengkonsumsi jus melon, dikarenakan buah melon memiliki kandungan banyak nutrisi yang dibutuhkan oleh tubuh manusia. Hal ini sebagaimana pendapat Harjana (2013) bahwa dalam 100 gram daging buah melon memiliki zat gizi penting, seperti: karbohidrat $14,8 \mathrm{gr}$, protein $1,55 \mathrm{gr}$, lemak $0,5 \mathrm{gr}$, potassium $546,9 \mathrm{mg}$, vitamin A 5.706,5 iu (mencakup 64\% kebutuhan vitamin A harian), dan vitamin C 74,7 mg.

Penelitian ini membuktikan bahwa dengan mengkonsumsi tablet $\mathrm{Fe}$ bersamaan dengan mengkonsumsi jus melon baik 100 gr, 150 gr maupun 200 gr setiap hari secara rutin dapat meningkatkan kadar hemoglobin pada ibu hamil. Seorang ibu hamil membutuhkan $85 \mathrm{mg}$ vitamin C perhari, sedangkan dalam 100 gram melon mengandung $74,7 \mathrm{mg}$ vitamin $\mathrm{C}$.

Hasil penelitian ini sesuai dengan hasil penelitian yang dilakukan oleh Hariyadi, dkk pada tahun 2015 yang menunjukkan bahwa konsumsi vitamin C akan meningkatkan kadar hemoglobin ibu hamil. Artinya semakin sering seseorang mengkonsumsi vitamin $\mathrm{C}$ maka semakin tinggi kadar hemoglobin ibu hamil.

\section{SIMPULAN DAN SARAN}

\section{Simpulan}

Terdapat perubahan kadar hemoglobin ibu hamil pada kelompok kontrol dan kelompok perlakuan. Pada kelompok kontrol terdapat perubahan kadar hemoglobin dengan nilai p-value 0,022. Ada perubahan kadar hemoglobin pada kelompok perlakuan pemberian jus melon 100 gr dengan nilai p-value 0,004 dan pemberian jus melon 200 gr dengan nilai p-value 0,000 , semetara untuk pemberian jus melon 150 gr tidak terdapat perubahan yang signifikan terhadap kadar hemoglobin pada ibu hamil.Terdapat perbedaan kadar hemoglobin pada perlakuan jus melon 200 gr dengan kontrol dengan $p=0,001$ dan IK 95\% dan terdapat perbedaan kadar hemoglobin perlakuan jus melon 200 gr dengan jus 100 gr dengan $p=0,017$ dan IK 95\%.

\section{Saran}

Bagi ibu hamil agar tablet Fe yang dikonsumsi ibu hamil terserap secara maksimal oleh tubuh sebaiknya ibu mengkonsumsi vitamin $\mathrm{C}$ atau dengan buah melon agar terhindar dari anemia selama kehamilan. Bagi Puskesmas agar mensosialisasikan kepada seluruh tenaga pelayanan kesehatan tentang melon yang mengandung vitamin $\mathrm{C}$ merupakan faktor penting dalam proses penyerapan zat besi. Bagi bidan agar memberikan penyuluhan guna meningkatkan pengetahuan ibu tentang nutrisi ibu hamil yang mana nutrisi ibu hamil akan mempengaruhi kesehatan ibu hamil. 


\section{DAFTAR PUSTAKA}

Alfi, 2013. Buah Melon dan kandungannya. Jakarta : Salemba Medika

Astriana, W. 2017. Kejadian Anemia pada Ibu hamil ditinjau dari Paritas dan Usia. Aisyah: Jurnal Ilmu Kesehatan 2(2) 2017, 123-130

Depkes RI. 2008. Pedoman Penanggulangan Anemia Gizi di Indonesia. Jakarta : Direktorat Bina Gizi Masyarakat.

Dinas Kesehatan Provinsi Jawa Tengah (2016). Dinas Kesehatan Jawa Tengah. Profil Keehatan Jawa tengah Tahun 2016.Harjana, D. 2013. Manfaat Buah Melon dan Kandungan Nutrisinya. Yogyakarta : Pustaka Rihama.

Kemenkes RI. 2017. Profil Kesehatan Indonesia 2016. Keputusan Menteri kesehatan Republik Indonesia. Jakarta

Manuaba. 2008. Ilmu Kebidanan, Penyakit Kandungan dan KB untuk Pendidikan Bidan. Jakarta : EGC.

Mariza, A. 2016. Hubungan Pendidikan dan Sosial Ekonomi dengan Kejadian anemia pada Ibu Hmail di BPS T Yohan Way Halim Bandar Lampung tahun 2015.Jurnal Kesehatan Holistik Vol10, No 1, Januari 2016 “ 5-8

Purwandari, A et al. 2016. Faktor-faktor yang berhubungan dengan kejadian Anemia. Jidan Jurnal Ilmiah Bidan. ISSN : 2339-1731

Rukmana. 1994. Bertanam sayur dalam pot. Jakarta :Redaksi Trubus

Sumiarsih dkk. 2018. Faktor-faktor yang mempengaruhi Hemoglobin ibu hamil trimester III. Placentum jurnal Kesehatan dan aplikasinya. Vol. 6. 2018

Sarwono.2010. Ilmu Kebidanan. Jakarta : Yayasan Bina Pustaka Sarwono Prawirohardjo

Saifudin, A.B. 2006. Buku Panduan Praktis Pelayanan Kesehatan Maternal dan Neonatal. Jakarta: Yayasan Bina Pustaka Sarwono Prawiroharjo.

Saifuddin. 2002. Ilmu Kebidanan. Jakarta : Bina Pustaka Sarwono Prawirohardjo

Shinta, Anisa. 2012. Hubungan antara kadar Hemoglobin dengan prestasi belajar siswi SMP Negeri 25 Semarang. Skripsi Fakultas Kesehatan Masyarakat Universitas Negeri Semarang.http://digilib.unnes.ac.id. diakses tanggal 9 April 2016.

Sediaoetama, A,D. 2006. Ilmu Gizi. Jilid I Cetakan Keenam. Jakarta : Dian Rakyat

Winkjosastro, H. 2015. Ilmu Kebidanan. Jakarta: Yayasan Bina Pustaka Sarwono Prawiroharjo. 